\title{
Investigating the Mediating Effect of the Role Stressor in the Relationship Between Type A Personality and Auditor Burnout
}

\author{
Indah Anisykurlillah ${ }^{1,2,}{ }^{*}$, Zulaikha $^{1}$, Farida N. Istiqomah $^{2}$ \\ ${ }^{1}$ Diponegoro University, Semarang, Indonesia \\ ${ }^{2}$ Semarang State University, Semarang, Indonesia \\ "Corresponding Email: indah_anis@mail.unnes.ac.id
}

\begin{abstract}
The research investigates the mediating effect of role conflict, role ambiguity, role overload, and job insecurity in the type A personality on the auditor's burnout. The population-based direct questionnaire was performed on data obtained from the public accountant's auditor in Central Java, Indonesia. The structural equation model analysis is used for hypothesis testing. The results showed that role conflict and job insecurity significantly mediated type A personality to auditor burnout. However, the research did not find evidence of the role effect of ambiguity and role overload on burnout. Suggestions for the public accountant recognize auditors' personalities, arranging work schedules and work assignments, and explaining the standards set out to prevent job burnout. Further research should be conducted to identify more specific determinants by classifying auditors' levels and job length.
\end{abstract}

Keywords: role conflict, role ambiguity, role overload, and job insecurity, type a personality, auditor burnout

\section{INTRODUCTION}

Auditors are one of the high-stress levels professions [1]. For example, in an audit activities context, the auditor's stress can be closely observed in a certified public accounting (CPA) firm. The auditors must communicate with multiple CPA parties which have varied demands and expectations for auditor decisions. In addition, the auditors are responsible for marginal activities [2]. One of the critical stress sources is workplace stress [3], causing several problems, such as role conflicts, ambiguity, role overload, and job insecurity, which may cause work burnouts of the auditor.

Although individual characteristics can also play an important role in determining burnout, most research in burnout auditors still focuses on the relationship between environmental factors [4]. Research on role stress models did not include personality type as a variable mediating the correlation between role stressors and burnout $[3,5]$. Auditor personality type A who be performanceoriented, time-disciplined, ambitious, and competitive, will be considered by the CPA firm when evaluating auditor performance and determining the appropriate audit team [6].

The studies that investigated the relationship between role stressors and burnout provides inconclusive results $[3,7]$. According to several studies, the following role stressors have the most significant positive impact on auditor job security: role conflict, role ambiguity, role overload, and burnout $[3,7,8]$. The findings, on the other hand, revealed that such: role ambiguity [5], role conflict [9], role overload [10] do not affect auditor burnout, and job insecurity reduces employee burnout [11]. Various burnout research focuses on the relationship between environmental factors and individual characteristics. Such attractive personality types are carried out, particularly since they are rarely disclosed for the auditor profession in Indonesia [12].

Other research has found that personality type A moderates some role stressors, such as role conflict and role overload, on auditor burnout [2,5], but it has not demonstrated all role stressors. Personality type is figured to have no direct auditors to burnout auditor unless mediated by working conditions controlled by the CPA firm's management [13]. 
This study's purpose is to investigate the mediating effects of role conflict, role ambiguity, role overload, and job insecurity on burnout for auditors with type A's personality. This study is expected to contribute to CPA management, particularly in improving working conditions and managing auditor resources. By involving the auditor's personality type, this research is also likely to be an empirical reference in the accounting literature, particularly regarding role stressors: role conflict, role ambiguity, role overload, and job burnout.

Based on role theory, this study hypothesizes that auditors with appropriate personality types can control the occurrence of auditor burnout through the mediation of role stressors. For example, auditors with type A personalities are more likely to burn out when they face conflict over their roles (role conflict), ambiguous role situations (role ambiguity), excessive work roles (role overload), and high job insecurity $[3,5,7]$.

Auditors with type A personalities will experience more stress due to their competitive, impatient nature, particularly in an environment with role conflict, role ambiguity, role overload, and job security [2,5]. Several previous studies have highlighted that it is not behavior patterns meaningful in a person's psychology, but whether they can cope with role problems more effectively [10]. Based on the above hypothesis can be formulated as follows:

H1: Role conflict significantly influence auditor burnout

$\mathrm{H} 2$ : Role ambiguity significantly affects auditor burnout.

H3: Role overload significantly influences auditor burnout.

H4: Job insecurity significantly influences auditor burnout.

H5: Role conflict mediates the relationship between type A personality on auditor burnout.

H6:Role ambiguity mediates the relationship between type A personality on auditor burnout.

$\mathrm{H} 7$ : Role overload mediates the relationship between type A personality on auditor burnout.

H8: Job insecurity memediasi hubungan antara type A personality terhadap auditor burnout.

\section{METHOD}

The research population consists of auditors who work at a CPA firm in Semarang City listed in the IAPI Directory in 2019. There are 23 CPA firms in Semarang City, with a total of 270 auditors. The sample was chosen with a minimum Slovin sample frame of 23 data because the auditor was busy and unwilling to answer the questionnaire during the mid-year peak season. The questionnaire is delivered directly to obtain the highest response rate. The questionnaire with a Likert scale on the variables role ambiguity (RA) and role conflict (RC) from Jones et al. [9], role overload (RO), job insecurity (JI), auditor burnout (AB) from Bloom et al. and Suprasto et al. $[14,15]$ and type A personality (TP) from Green [16].

The research utilizes a structural equational model with the following three steps. First, testing the outer model, which includes assessing the value of reliability and composite reliability indicators and average variance extracted (AVE) and discriminant validity. The second test of the inner model is the variance analysis (R2). The third test consists of average Path coefficient (APC) and average R-square through fitness (GoF) criteria (ARS). The final examination consists of testing the hypothesis with a path factor of $5 \%$. Provision is made to assess the impact of mediation by taking into consideration assumptions that (1) there must be substantial direct relation of endogenous and exogenous structures, (2) there must be a direct relation between endogenous constructs and mediators, and (3) there must also be an indirect relationship between exogenous constructions through mediators and endogenous structures. The mediation role exists when the above conditions are fulfilled.

\section{RESULT AND DISCUSSION}

Data was collected from the 13 CPA firms by 59 auditors $(21.58 \%)$ willing to participate in the survey with two weeks. Women dominate respondents at 61.02 $\%$, but that's not a problem because auditors' expertise isn't just gender. The majority of respondents aged 20 to 25 years were $52.54 \%$, with a bachelor's degree of $71.19 \%$. The level of the auditors is dominated by junior auditors of $50.58 \%$, most of whom have working experience from 1 to 5 years $(72.88 \%)$.

The outer models' evaluation shows that the loading factor greater than 0.6 and the AVE value greater than 0.5 for each variable indicator also means each variable is valid. Every variable has a composite value, and Cronbach alpha is defined as more than 0.7 so that each variable is classified as reliable. Inner models show that the R2 value and the adjusted R2 were 0.33 to 0.67 , except job safety and role overload, classified as moderate. The test results show that the importance of APC and ARS are significant at 5\% alpha. This result demonstrates the fit of the equation model. 
Table 1. Result Assessment

\begin{tabular}{|c|c|c|c|c|c|c|c|c|c|}
\hline & $\begin{array}{l}\text { Loading } \\
\text { Factor }\end{array}$ & $p$ & & & & $\begin{array}{l}\text { Loading } \\
\text { Factor }\end{array}$ & $p$ & $\begin{array}{l}\text { Sobel } \\
\text { Value }\end{array}$ & $p$ \\
\hline Panel A & & & & Panel B & & & & & \\
\hline $\mathrm{JI}->\mathrm{AB}$ & 0.275 & $0.032 *$ & (H4) & $\mathrm{TP} \rightarrow \mathrm{JI}->\mathrm{AB}$ & (H8) & 0.125 & 0.084 & 1.624 & 0.056 \\
\hline $\mathrm{RA} \rightarrow \mathrm{AB}$ & 0.214 & 0.086 & $(\mathrm{H} 2)$ & $\mathrm{TP} \rightarrow \mathrm{RA} \rightarrow \mathrm{AB}$ & (H6) & 0.121 & 0.149 & 1.668 & 0.067 \\
\hline $\mathrm{RC} \rightarrow \mathrm{AB}$ & 0.437 & $0.002 *$ & (H1) & $\mathrm{TP} \rightarrow \mathrm{RC} \rightarrow \mathrm{AB}$ & (H5) & 0.332 & $0.004 *$ & 3.008 & $0.001 *$ \\
\hline $\mathrm{RO}->\mathrm{AB}$ & 0.110 & 0.282 & (H3) & $\mathrm{TP} \rightarrow \mathrm{RO} \rightarrow \mathrm{AB}$ & (H7) & 0.015 & 0.611 & 0.628 & 0.264 \\
\hline $\mathrm{TP}->\mathrm{JI}$ & 0.454 & $0.000 *$ & & & & & & & \\
\hline $\mathrm{TP}$-> RA & 0.568 & $0.000 *$ & & & & & & & \\
\hline $\mathrm{TP} \rightarrow \mathrm{RC}$ & 0.759 & $0.000 *$ & & & & & & & \\
\hline $\mathrm{TP}$-> RO & 0.133 & 0.438 & & & & & & & \\
\hline
\end{tabular}

demonstrates $\mathrm{H} 1$ and $\mathrm{H} 4$ are not rejected. In contrast, $\mathrm{H} 2$ and $\mathrm{H} 3$ are rejected at alpha $5 \%$. These results indicate that auditors' burnout is significantly determined by role conflict and job insecurity. In contrast, role ambiguity and role overload do not have a significant impact. This finding is consistent with the role theory of Kahn et al. [17], explaining that conflict of role occurs when the auditor is simultaneously confined to different pressures because it often continues to operate within the boundary. After all, the other parties participate in the changing audit of age, occupation, gender, and interests should manage their role.

Auditors should immediately adapt to resolve work, family, social, and other personal interests and responsibilities [18]. Empirically, job insecurity affects auditor burnout. This finding confirms that the working environment and conditions of the auditor do not support the development of work convenience $[2,11,15]$. This evidence is understandable, as most people were young women, productive and relatively new employed, faced with stressful situations and a different atmosphere, leading to role conflict and work discomfort. Consequently, the auditor conflict role and the continuing work discomfort will lead to job burnout [19].

The results found that role ambiguity and role overload do not contribute to auditors feeling overstressed. Survey respondents show that nearly all auditors $(81.2 \%)$ believe the audit assignment clearly defines purpose and planning. In the case of $78.9 \%$ of auditors, they were given sufficient information to appropriately divide their time and workload. According clear, not direct, challenging to interpret, or inconsistent with comprehension, as a result of which the notice is deemed ambiguous or contains elements of conflict [1], which is consistent with previous research findings $[2,18]$.

Time-limited audit assignments to respondents as a check on assignment completion encourage increased auditor performance [20]. Estimated audit fees are based on the schedule, auditor assignment, and scope of the study and serve as a basis for evaluating auditor performance [21]. The majority of respondents are junior auditors who receive an adequate amount of work in quantity and quality.

We performed $\mathrm{H} 5, \mathrm{H} 6, \mathrm{H} 7$, and $\mathrm{H} 8$ testing to analyze the effect on the auditor's personality type. Table 1 Panel $\mathrm{B}$ shows that only H5 is statistically significant at $=5 \%$. It is demonstrated that the loading factor of the indirect effect of mediating role conflict on type A personality on auditor burnout is substantial. Panel A shows that role conflict, role ambiguity, and job insecurity significantly affect auditor burnout. Auditor type A personality has a significant effect on role conflict, role ambiguity, and job insecurity. Still, the third mediates' assumption that the loading factor value increases do not occur unless role conflicts. Therefore, burnout is mediated by role stressors: role conflict, role ambiguity, role overload, and job insecurity.

According to Intiyas \& Nahartyo's [5] research, role conflict mediates the relationship between type A personality and auditor burnout. Because of conflicting 
expectations, the auditor may experience role conflict. The auditor's incompatibility with his duties, resources, work rules, or policies may also cause role conflict. Avoid the role of a good employee if the auditor acts professionally and following the code of ethics. Auditors with type A personalities, according to personality theory, want complete control over everything to become the best [22].

A total of $81.7 \%$ of auditors with type A personalities always tried hard in many ways, but it is impossible to hold more than one role, ideally in a running role as auditor. These findings suggest that the influence of type A personality creates more tension and pressure on CPA auditors, causing them to be impatient, making them more likely to develop symptoms of work stress. Auditors with type A personalities who are unable to meet the expectations of those around them may burn out due to role conflict. Auditors are frequently involved in situations that necessitate an emotionally demanding role due to the nature of their work, assignments, work pressures, and interactions with others who have varying expectations [21].

The performance evaluation of the auditor determines individual characteristics, such as inappropriate expectations, differences between auditors, and assignments of work, resources, rules/policies that cause conflicts in the role. As CPA firm efficient employees, the auditors face regulatory requirements and have to adhere to ethical conduct [10]. In many situations, two or more roles lead to role conflicts that burn out the auditor. The auditor's emotional composure will lead to job burnout will be increased in working circumstances with role conflicts [23]. Type A auditors show very ambitiously, vigorous, impatient, competitive, hard work, and hasty features. Type A auditing profession offers more conflicting roles and stress at work [7][4].

By carrying out a series of training and information dissemination, the CPA firm can address such a problem to reduce the gap in expectations because of the conflict of roles [24]. In addition, CPA firm policies aim to investigate and improve work schedules and audit assignments of auditors. For example, it would draw up a list of workloads and procedures compiled and transmitted through standard procedures so that auditors can better manage roles to reduce the impact of conflicting roles on job burnout [22][25].

\section{CONCLUSION}

The empirical findings indicate that role conflict and job insecurity is significantly associated with auditor burnout, whereas role ambiguity and role overload are not. Subsequent results indicate that role conflict acts as a moderator in the relationship between auditor burnout and type A personality. Therefore, contribute practically to CPA's policy of managing assignment burdens, work schedules, and procedures so that auditors have a better understanding of how to manage their work roles and responsibilities to mitigate the effect of role conflict on job burnout. The following research was conducted to examine additional moderating and mediating variables. The results will bolster the antecedents and consequences of role stressors and auditor burnout using various auditor demographic variables.

\section{AUTHORS' CONTRIBUTIONS}

Indah Anisykurillah and Farida $\mathrm{N}$ Istiqomah conceived the presented idea, developed the problem, theory, and methodology, and then performed the computations. Zulaikha verified the analytical methods to investigate the mediating role stressors on auditor burnout and supervised this work's findings. All authors discussed the results and contributed to the final manuscript.

\section{ACKNOWLEDGMENTS}

This research was supported by research grants awarded from Semarang State University in 2020. The authors would like to thank the referees for their helpful comments and suggestions for improving a previous version of this paper. The authors also would like to thank two anonymous reviewers for their valuable feedback.

\section{REFERENCES}

[1] I. G. A. N. Budiasih, 'Burnout Pada Auditor di Kantor Akuntan Publik Provinsi Bali', J. Ris. Akunt. dan Keuang., vol. 5, no. 3, pp. 79-92, 2017.

[2] N. M. Wiryathi, N. K. Rasmini, and M. G. Wirakusuma, 'Pengaruh Role Stressors pada Burnout Auditor dengan Kecerdasan Emosional sebagai Variabel Pemoderasi', E-Jurnal Ekon. dan Bisnis Univ. Udayana, vol. 5, no. 3, pp. 227-244, 2014.

[3] E. Murtiasri, 'Anteseden dan Konsekuensi Burnout pada Auditor: Pengembangan Terhadap Role Stress Model', Maksi, vol. 7, no. 1, pp. 
131-149, 2007.

[4] C. Maslach, M. P. Leiter, and W. B. Schaufeli, 'Job Burnout', Annu. Rev. Psycology, vol. 52, pp. 397-422, 2001.

[5] I. Utami and E. Nahartyo, 'The effect of type a personality on auditor burnout: Evidence from Indonesia', Account. Tax., vol. 5, no. 2, pp. 89103, 2013.

[6] J. W. F. Catto et al., 'Artificial intelligence in predicting bladder cancer outcome: A comparison of neuro-fuzzy modeling and artificial neural networks,' Clin. Cancer Res., vol. 9, no. 11, pp. 4172-4177, 2003.

[7] G. Wu, Z. Hu, and J. Zheng, 'Role stress, job burnout, and job performance in construction project managers: The moderating role of career calling,' Int. J. Environ. Res. Public Health, vol. 16, no. 13, 2019.

[8] N. Tilakdharee, S. Ramidial, and S. B. Parumasur, 'The relationship between job insecurity and burnout,' South African J. Econ. Manag. Sci., vol. 13, no. 3, pp. 254-271, 2010.

[9] A. Jones, C. S. Norman, and B. Wier, 'Healthy Lifestyle as a Coping Mechanism for Role Stress in Public Accounting,' Behav. Res. Account. Am. Account. Assoc., vol. 22, no. 1, pp. 21-41, 2010.

[10] A. Riantiningtyas, 'Pengaruh role stressors dan self esteem terhadap timbulnya burnout dan konsekuensinya terhadap job outcomes auditor di Indonesia', Univ. diponegoro, 2009.

[11] F. Green, 'Health effects of job insecurity, IZA World Labor, vol. 212, pp. 1-10, 2015.

[12] N. W. Rustiarini, 'Sifat kepribadian sebagai pemoderasi hubungan stres kerja dan perilaku disfungsional audit', J. Akunt. dan Keuang. Indones., vol. 11, no. 1, pp. 1-19, 2014.

[13] K. A. Graham, 'Auditor Personal Characteristics and Fraud Detection Skill: The Mediating Role of Professional Sceptism', University of Ghana, 2019.

[14] S. J. Ashford, C. Lee, and P. Bobko, 'Content, Cause, and Consequences of Job Insecurity: A Theory-Based Measure and Substantive Test,' Acad. Manag. J., vol. 32, no. 4, pp. 803-829, 1989.

[15] V. Blom, A. Richter, L. Hallsten, and P. Svedberg, 'The associations between job insecurity, depressive symptoms, and burnout: The role of performance-based self-esteem,' Econ. Ind. Democr., vol. 39, no. 1, pp. 48-63, 2018.

[16] D. Perlman, L. A. Peplau, and S. E. Goldston, 'Loneliness research: A survey of empirical findings,' Prev. Harmful consequences Sev. persistent loneliness, pp. 13-46, 1984.

[17] R. L. Kahn, D. M. Wolfe, R. P. Quinn, J. D. Snoek, and R. A. Rosenthal, 'Organizational stress: Studies in role conflict and ambiguity.', 1964.

[18] I. Rachmawati Purnima and Ferdiansyah, 'Pengaruh role ambiguity, role conflict, dan role overload terhadap burnout ( Studi Empiris pada Auditor di KAP Kota Bandung )', J. Sains Purnima, vol. 3, no. 2, 2011.

[19] T. Fogarty, J. Singh, G. Rhoads, and R. Moore, 'Antecedents and consequences of burnout in accounting: Beyond the role stress model,' Behav. Res. Account., vol. 12, p. 31, 2000.

[20] H. B. Suprasto, D. Ariyanto, I. K. Jati, N. L. S. Widhiyani, and I. K. Suryanawa, 'Ability of Religiosity and Emotional Intelligence to Moderate the Effect of Role Conflict, Role Ambiguity, Role Overload, and Job Insecurity on Burnout of Tax Consultants in Bali Province,' Research J. Financ. Account., vol. 8, no. 18, pp. 7-15, 2017.

[21] M. Salehi, F. Seyyed, and S. Farhangdoust, 'The impact of personal characteristics, quality of working life and psychological well-being on job burnout among Iranian external auditors,' Int. J. Organ. Theory Behav., 2020.

[22] D. Y. Jeung, C. Kim, and S. J. Chang, 'Emotional labor and burnout: A review of the literature, Yonsei Med. J., vol. 59, no. 2, pp. 187-193, 2018.

[23] M. Al Shbail, Z. Salleh, and M. N. Mohd Nor, 'Antecedents of burnout and its relationship to internal audit quality, Bus. Econ. Horizons, vol. 14, no. 4, pp. 789-817, 2018.

[24] M. Vahdani and A. Zahmatkesh, 'Investigating the Effect of Role Ambiguity on the Relationship Between Conflict Management Styles and Job Exhaustion of Public Sector Accountants,' Gov. Account., vol. 6, no. 1, pp. 115-130, 2019.

[25] Q. Hongdao, A. Mumtaz, H. Mukhtar, H. A. R. Saleem, and S. Azam, 'Corruption Prevention and Economic Growth: A Mediating Effect of Rule of Law,' Int. J. Soc. Sci. Stud., vol. 6, no. 2, p. 128, 2018. 